\title{
Identification and Management of Colletotrichum acutatum on Immature Bell Peppers
}

Melanie L. Lewis Ivey, Cristian Nava-Diaz, and Sally A. Miller, Department of Plant Pathology, The Ohio State University, Ohio Agricultural Research and Development Center, Wooster 44691

\begin{abstract}
Lewis Ivey, M. L., Nava-Diaz, C., and Miller, S. A. 2004. Identification and management of Colletotrichum acutatum on immature bell peppers. Plant Dis. 88:1198-1204.

Farmers in northwestern Ohio reported severe losses due to anthracnose in immature (green) bell pepper as early as 1998. Two fungal isolates (AN1 and AN2) were recovered from immature fruit showing severe anthracnose symptoms. The pathogen was identified as Colletotrichum acutatum based on morphological and cultural characteristics, polymerase chain reaction (PCR) assay with the $C$. acutatum species-specific primer (CaInt2), and nucleotide sequencing. Isolate AN1 was pathogenic on immature pepper, tomato, and strawberry. Twenty-two bell pepper cultivars evaluated in field trials were all susceptible to C. acutatum AN1 and AN2, but the degree of susceptibility varied among cultivars. 'Crusader', 'Valiant', and 'ACX229' were the most susceptible, while 'North Star' and 'Paladin' were least susceptible. The fungicides pyraclostrobin (Cabrio) alternated with manganese ethylenebisdithiocarbamate (Manex), chlorothalonil (Bravo Ultrex) alone, Manex plus copper hydroxide (Kocide 2000), and pyraclostrobin + boscalid (BAS $516=$ Pristine) alternated with Manex significantly reduced anthracnose incidence and intensity in bell peppers compared with the untreated control.
\end{abstract}

Anthracnose, caused by various species of Colletotrichum, causes significant damage to a wide variety of vegetables, legumes, and fruit crops worldwide. The disease can occur on leaves, stems, and both preharvest and postharvest fruit. Typical fruit symptoms are circular or angular sunken lesions that produce pink to orange conidial masses. Under severe disease pressure, lesions may coalesce. Conidial masses may occur scattered or in concentric rings on the lesions (24).

In Ohio, anthracnose is a common problem on strawberries, tomatoes, potatoes, and peppers. Three species of Colletotrichum are known to occur on strawberry: C. acutatum Simmonds (50,51), C. gloeosporioides (Penz.) Penz. et Sacc. (15), and C. fragariae (M. Ellis, personal communication); one species on tomato and potato: C. coccodes (14); and two species on bell pepper: C. gloeosporioides $(14,32)$ and $C$. coccodes (S. Miller, unpublished). Until the late 1990s, anthracnose was observed primarily on processing peppers allowed to reach maturity prior to harvest, and was associated with $C$. coccodes. It was not observed on fresh market peppers harvested immature (green) until 1998, when farmers in northwestern Ohio reported

Corresponding author: Sally A. Miller
E-mail: miller.769@osu.edu

Accepted for publication 10 June 2004.

Publication no. D-2004-0823-01R

(C) 2004 The American Phytopathological Society severe outbreaks of an anthracnose-like disease. Since then, this disease has been observed each year with varying incidence and intensity, and has spread to other areas in the state. The pathogen causes multiple lesions on the fruit, sporulates quickly and profusely (Fig. 1), and spreads rapidly throughout the pepper crop, resulting in up to $100 \%$ yield loss (S. Miller, unpublished). Initial observations indicated that this form of anthracnose was not caused by C. coccodes.

Until recently, Colletotrichum species were identified almost exclusively based

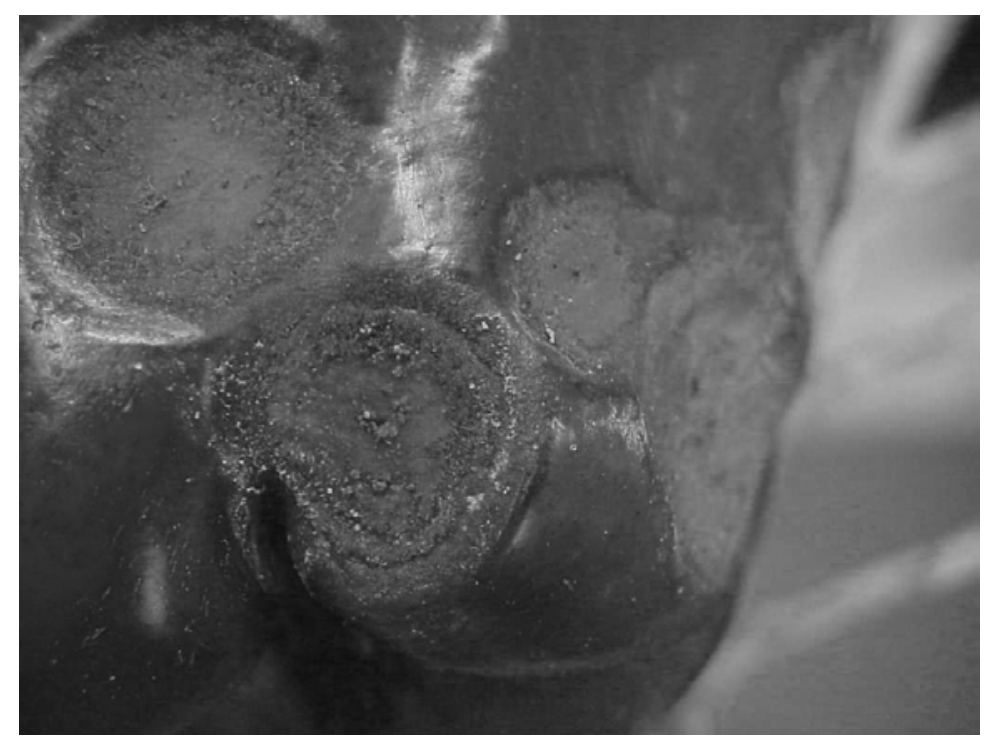

Fig. 1. Anthracnose symptoms caused by Colletotrichum acutatum on immature bell pepper fruit from northwestern Ohio. on morphological and cultural characteristics. Characters commonly used to differentiate Colletotrichum species include conidial morphology, presence or absence of setae, presence or absence of the teleomorph, colony color, pigment production, growth rate, and appressorium features (48). Typical characteristics of C. gloeosporioides, $C$. acutatum, C. coccodes, and $C$. fragariae have been described previously $(2,13,23,37,38)$. However, definitive identification of Colletotrichum species based on morphology is difficult because isolates have overlapping ranges of conidial and colony characteristics and because variation in morphology is accepted for isolates within a species (48).

A number of molecular methods have been used to characterize species of Colletotrichum. Arbitrary primed polymerase chain reaction (ap-PCR) $(18,19)$, restriction fragment length polymorphisms (RFLPs) of PCR-amplified ribosomal DNA (rDNA) $(8,9,31,34)$, and nucleotide sequences of the internal transcribed spacer (ITS) regions of rDNA $(12,34$, 36,45 ) have all been used to differentiate among isolates of Colletotrichum species from a diverse host range. Species-specific primers $(14,37,38,48-50)$ based on the ITS regions of different species of Colletotrichum have also been used to differentiate between $C$. gloeosporioides, C. coccodes, and C. acutatum (10,20-22,35,36). 
The fungicide traditionally recommended for anthracnose management in peppers (manganese ethylenebisdithiocarbamate [Maneb]; 42) does not consistently control the severe form of anthracnose on pepper fruit. The strobilurin fungicides azoxystrobin (Quadris), trifloxystrobin (Flint), and pyraclostrobin (Cabrio) have recently been labeled for the control of anthracnose on peppers, but only preliminary reports are available on the efficacy of these fungicides against the severe form of the disease $(4-6,30,33)$. Host resistance may provide additional protection, but the level of resistance among bell pepper cultivars to this disease has not been determined. The purpose of this work was to identify the species of Colletotrichum causing the severe form of anthracnose on immature bell pepper fruit using both classical and molecular techniques. In addition, we evaluated commercial pepper cultivars for resistance to the pathogen and determined the efficacy of various fungicides for disease control in order to develop recommendations for management by Ohio growers. The virulence of these isolates on strawberry, a host of $C$. $a c u$ tatum, and tomato, often grown in close proximity to peppers and susceptible to other species of Colletotrichum, was also evaluated.

\section{MATERIALS AND METHODS}

Pathogen isolation and maintenance. Isolates of Colletotrichum spp. were recovered from anthracnose lesions by cutting a small section of the lesion from the leading edge, surface sterilizing in $70 \%$ ethanol, and culturing on potato dextrose agar medium (PDA; Difco Laboratories, Detroit, MI). Monoconidial cultures were produced for each isolate and maintained on PDA at room temperature. Isolates AN1 and AN2 were recovered from immature pepper fruit from a farm in northwestern Ohio. Cultures were stored on PDA slants at $10^{\circ} \mathrm{C}$ and transferred every 4 weeks. For long-term storage, three agar plugs (\#3 cork borer) cut from the leading edge of cultures actively growing on PDA were suspended in $3 \mathrm{ml}$ of a $20 \%$ glycerol:17\% skim milk (1:1 $\mathrm{vol} / \mathrm{vol})$ solution and frozen at $-80^{\circ} \mathrm{C}$. Reference isolates of $C$. acutatum and $C$. gloeosporioides used in this study were acquired from sources shown in Table 1 and maintained as described above.

Colony and spore morphology. Isolates AN1 and AN2 were grown on PDA as described above. The appearance of the colonies, the occurrence of sectors, and the vegetative and reproductive structures were described after 7 days incubation. For conidial measurements, isolates AN1 and AN2 were cultured under continuous fluorescent light for 3 days at room temperature on PDA to promote sporulation. Spores were suspended in sterile water using a sterile needle. Length and width were measured for 30 conidia, and conidial shape was recorded at $\times 400$ magnification $(10 \times$ ocular, $40 \times$ objective) using bright field microscopy (Zeiss, Thornwood, NY).

DNA extraction. Colletotrichum isolates were grown in $100 \mathrm{ml}$ of glucosecasein (45) broth for 3 days at $25^{\circ} \mathrm{C}$ with shaking $(120 \mathrm{rpm})$. Mycelia were filtered through No. 3 Whatman paper and dried for $24 \mathrm{~h}$ at $60^{\circ} \mathrm{C}$. Dried mycelia were ground into a fine powder using liquid nitrogen, and total genomic DNA was extracted according to the protocol described by Lee and Taylor (29).

PCR amplification. Species-specific primers for C. gloeosporioides (CgInt; 5'GGCCTCCCGCCTCCGGGCGG-3') (36) and $C$. acutatum (CaInt-2; 5'-GGCGCCGGCCCCGTCACGGGGG-3') (4547) from the ITS1 region of the ribosomal DNA gene were used in combination with the conserved primer ITS4 (49). Each 25$\mu \mathrm{l}$ reaction mixture contained $2.5 \mu \mathrm{l}$ DNA $(50 \mathrm{ng} / \mu \mathrm{l}), 0.12 \mu \mathrm{l}$ of each $10 \mu \mathrm{M}$ primer, $0.08 \mu \mathrm{l}$ of $10 \mathrm{mM}$ dNTP, $0.5 \mu \mathrm{l}$ of Taq Polymerase $(5 \mathrm{U} / \mu \mathrm{l}), 1.5 \mu \mathrm{l}$ of $25 \mathrm{mM}$ $\mathrm{MgCl}, 2.5 \mu \mathrm{l}$ of $10 \times$ polymerase buffer, and $16.9 \mu \mathrm{l}$ of sterile milliQ water. PCR was performed in a MJR PTC-100 thermocycler (MJ Research Inc., Waltham, MA) using the following program: $5 \mathrm{~min}$ at $94^{\circ} \mathrm{C}, 30$ cycles of $1.5 \mathrm{~min}$ at $94^{\circ} \mathrm{C}, 2 \mathrm{~min}$ at $55^{\circ} \mathrm{C}$, and $3 \mathrm{~min}$ at $72^{\circ} \mathrm{C}$, and then a 10 min final extension at $72^{\circ} \mathrm{C}$. PCR products $(7 \mu \mathrm{l})$ were separated by horizontal gel electrophoresis in $1.5 \%$ agarose in $0.5 x$ TBE buffer at $100 \mathrm{~V}$ for $60 \mathrm{~min}$. Gels were stained in dilute ethidium bromide (2 $\mu \mathrm{g} / \mathrm{ml}$ ), visualized under UV light, and photographed using the Kodak Electrophoresis Documentation and Analysis System (EDAS) 290 (Eastman Kodak Company, New Haven, CT).

Sequence analysis. PCR products generated from primers CaInt-2/ITS4 and CgInt/ITS4 were purified using QIAquick PCR purification kits (Qiagen Inc., Chatsworth, CA) according to the manufacturer's instructions. Direct sequencing of purified amplification products was performed twice at the Plant-Microbe Genomics Facility, The Ohio State University, Columbus. Base calling and sequence quality were determined for both strands of the sequences generated using Mac PhrepMac Phrap software $(16,17)$. The software Sequencher (Sequencher 3.0, Gene Codes Corporation, Ann Arbor, MI) was used to assemble, edit, and generate high-quality sequences. Sequence alignments were performed and similarity values were cal- culated with the ClustalW algorithm in Mac Vector (Mac Vector 6.1, Oxford Molecular Ltd., Beaverton, OR) using default settings. GenBank, EMBL, DDBJ, and PDB databases were searched for sequence similarities using Gapped BLAST and PSI-BLAST programs (7).

Pathogenicity on pepper, tomato, and strawberry. Isolates AN1 and AN2 were cultured to promote sporulation as described above. Cultures were flooded with sterile distilled water and filtered through four layers of cheesecloth to remove mycelia. Conidia concentration was determined using a hemacytometer and adjusted to $4 \times$ $10^{5}$ conidia per $\mathrm{ml}$ using sterile distilled water. Immature bell pepper fruits were purchased from a local grocery store, and green and red tomato (PTO 8670I \#2) fruits were collected from greenhousegrown tomato plants and washed in tap water. The washed fruits were surfacedisinfected in $0.03 \%$ sodium hypochlorite for $2 \mathrm{~min}$, rinsed twice in sterile distilled water, and placed in plastic closed containers on wire mesh screens. Fruits were labeled with a permanent marker, and the point of inoculation was circled on each fruit. Wounded and nonwounded fruits were evaluated. Wounds approximately 2 $\mathrm{mm}$ deep were made using a 27.5 gauge sterile needle. Twenty microliters of the conidial suspension was dispensed onto the fruit (over the wound for wounded fruit). Control fruits were inoculated with $20 \mu \mathrm{l}$ of sterile distilled water. Sterile hot water was added to the bottom of each container, which was then capped tightly. Sterile hot water was added to the containers daily. Lesion diameter was measured 0 , $3,4,5,6$, and 10 days after inoculation. The tests were done three times.

Strawberry fruit were inoculated with isolates AN1, AN2, and Ca Mil-1. Spore suspensions were produced as described above. Strawberries ('Allstar') were planted in $15-\mathrm{cm}$ plastic pots containing a 2:1:1 mixture of Wooster silt loam, peat moss, and sand. Strawberry fruit just beginning to ripen were inoculated by spraying to runoff using an atomizer. Twelve fruit per isolate were inoculated, and deionized water was used as a negative control. Inoculated plants were incubated at 25 $\pm 2^{\circ} \mathrm{C}$ in a misting chamber for $24 \mathrm{~h}$ and then transferred to a greenhouse maintained at the same temperature. Plants were trickle irrigated two times per day with deionized water. Fruit were rated for anthracnose incidence after 10 days.

Table 1. Host, source, and species of Colletotrichum reference isolates

\begin{tabular}{llll}
\hline Isolate & Species & Host & Source \\
\hline Ca Ohio-1 & C. acutatum & Strawberry & M. Ellis \\
Ca Mil-1 & C. acutatum & Strawberry & M. Ellis \\
ATCC 58692 & C. gloeosporioides & Tomato & ATCC \\
ATCC 58696 & C. gloeosporioides & Strawberry & ATCC \\
GS & C. gloeosporioides & Apple & T. Sutton \\
GD & C. gloeosporioides & Apple & T. Sutton \\
\hline
\end{tabular}


Table 2. Treatments, rates, and application timing of fungicides applied to bell peppers inoculated with Colletotrichum acutatum isolates AN1 and AN2 in 2001 and 2002

\begin{tabular}{lcc}
\hline Treatment & Rate/ha & Application timing $^{\mathbf{x}}(\mathbf{w k})$ \\
\hline Quadris 2.08SC alt. $^{\mathrm{y}}$ & 0.409 liters & $1-2,4,6$ \\
Manex 37F & 4.2 liters & 3,5 \\
Manex 37F +z & 4.2 liters & $1-6$ \\
Kocide 2000 & $2.5 \mathrm{~kg}$ & $1-6$ \\
Manex 37F & 4.2 liters & $1-6$ \\
Bravo Ultrex 82.5WG & $2.2 \mathrm{~kg}$ & $1-6$ \\
Pristine (BAS 516) alt. & $1.2 \mathrm{~kg}$ & $1-2,4,6$ \\
Manex 37F & 4.2 liters & 3,5 \\
Cabrio 20EG alt. & $0.8 \mathrm{~kg}$ & $1-2,4,6$ \\
Manex 37F & 4.2 liters & 3,5 \\
Untreated & &
\end{tabular}

${ }^{\mathrm{x}}$ Fungicide treatments were applied on a 7- to 10-day schedule beginning 7 days before the first inoculation.

y Treatments were alternated according to the application timing.

${ }^{\mathrm{z}}$ Treatments were tank mixed prior to application.

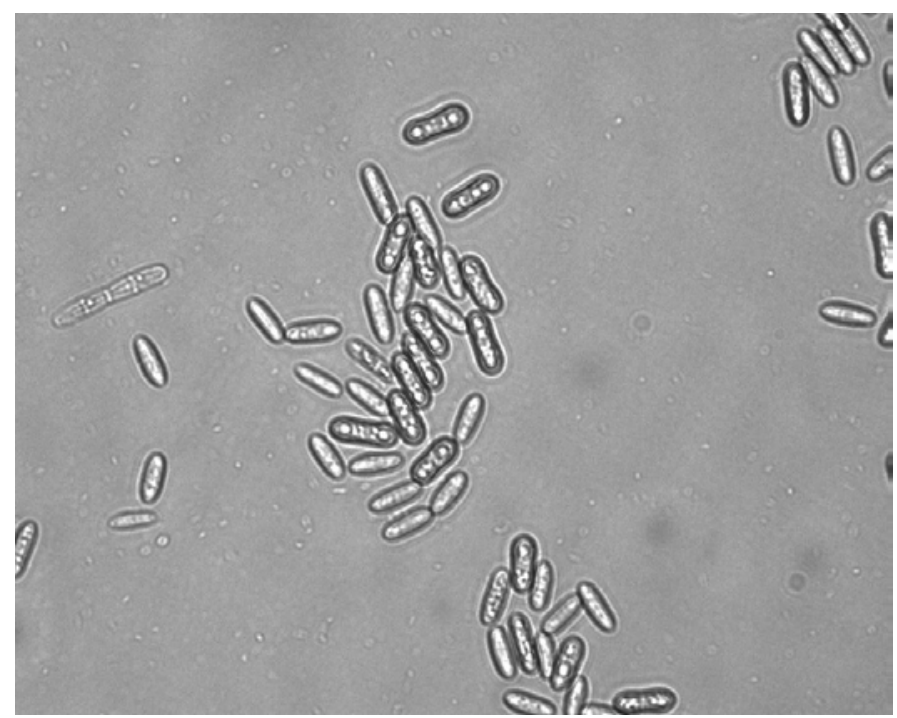

Fig. 2. Conidial morphology of Colletotrichum acutatum isolates AN1 and AN2 grown under continuous fluorescent light for 3 days at room temperature on potato dextrose agar (bright field microscopy, $\times 400)$.

Evaluation of fungicide efficacy and cultivar resistance. Field trials were conducted in 2001 and 2002 on Wooster silt loam at the Ohio Agricultural Research and Development Center, Wooster. The experimental sites were prepared and fertilized, and weeds and insects were managed according to standard commercial practices (42). Overhead irrigation was applied as needed. Pepper transplants raised in a greenhouse for 7 to 8 weeks in 200-cell flats were planted during the second week of June in both 2001 and 2002. Cultivar and fungicide trials were conducted as independent field experiments. For both cultivar and fungicide trials, the plots consisted of a row of 20 plants spaced $30.5 \mathrm{~cm}$ apart within the row. Rows were 91 and $107 \mathrm{~cm}$ on center for the fungicide and cultivar trials, respectively. Fungicide treatment rows were alternated with untreated border rows. All trials were arranged in a randomized complete block design with four replications. Twenty-two cultivars and six fungicide treatments were tested in 2001 and
2002. In 2001, the pepper cultivar 'North Star' was planted in the fungicide trial, and in 2002 a more susceptible cultivar ('ACX229') was planted. Fungicide treatments, rates, and application timings, and cultivars used are listed in Tables 2 and 3 , respectively. Fungicides were applied using a tractor mounted $\mathrm{CO}_{2}$ pressurized sprayer at $20 \mathrm{psi}$ (453 liter/ha) in 2001 and 40 psi (352 liter/ha) in 2002. Fungicide treatments were applied on a 7to 10-day schedule beginning 7 days before the first inoculation. Inoculum was prepared as described for the pathogenicity tests. Plants were inoculated with a mixture of AN1 and AN2 (2001: $4 \times 10^{5}$ conidia per ml; 2002: $4 \times 10^{3}$ conidia per ml) using a hand-held Herbi Sprayer (red nozzle; Micron, Herefordshire, UK) at 468 liter/ha and an approximate walking rate of $1.6 \mathrm{~s} / \mathrm{m}$. In both years, plants were inoculated at late flowering (early fruit set). In 2002, conidial concentration was decreased since disease pressure was very high the previous year. However, dry weather conditions in 2002 required that
Table 3. Cultivars and seed sources for bell peppers inoculated with Colletotrichum acutatum isolates AN1 and AN2 in 2001 and 2002

\begin{tabular}{ll}
\hline Cultivar & Source \\
\hline ACX 220 & Abbott and Cobb Inc. \\
ACX 229 & Abbott and Cobb Inc. \\
Summer Sweet \#830 & Abbott and Cobb Inc. \\
ACX 217 & Abbott and Cobb Inc. \\
Valiant & Seminis Inc. \\
Red Knight X3R & Seminis Inc. \\
North Star & Seminis Inc. \\
Sir Galahad & Seminis Inc. \\
Iron Sides X3R & Seminis Inc. \\
PS304496 & Seminis Inc. \\
Stiletto & Syngenta Seeds Inc. \\
Crusader & Syngenta Seeds Inc. \\
PR99R-2 & Syngenta Seeds Inc. \\
PR99RY-3 & Syngenta Seeds Inc. \\
PR99R-4 & Syngenta Seeds Inc. \\
Legionaire & Syngenta Seeds Inc. \\
PR2000-516 & Syngenta Seeds Inc. \\
Commandant & Syngenta Seeds Inc. \\
Lafayette & Syngenta Seeds Inc. \\
Colossal & Syngenta Seeds Inc. \\
Brigadier & Syngenta Seeds Inc. \\
Paladin & Syngenta Seeds Inc. \\
\hline
\end{tabular}

Table 4. Polymerase chain reaction amplification results using species-specific primers for Colletotrichum acutatum (CaInt2/ITS4) and $C$. gloeosporioides (CgInt/ITS4) from strawberry (Ca Ohio-1 and Mil-1), immature bell pepper fruit (AN1 and AN2), and the American Type Culture Collection (ATCC) (ATCC 58692 and 58696)

\begin{tabular}{lcc}
\hline Isolate & CaInt2/ITS4 & CgInt/ITS4 \\
\hline Ca Ohio-1 & + & - \\
Ca Mil-1 & + & - \\
GS & - & + \\
GD & - & + \\
AN1 & + & - \\
AN2 & + & - \\
ATCC 58692 & + & - \\
ATCC 58696 & + & - \\
\hline
\end{tabular}

the plants be reinoculated 24 days after the first inoculation. Prior to all inoculations, plants were overhead-irrigated with $5 \mathrm{~cm}$ of water. Green fruit were handharvested from all the plants in each row in 2001 and from the center 10 plants of each row in 2002. Fruits were sorted into categories based on the number of lesions $(0,1,2$ to 3 , or 4 to 10 lesions per fruit) and weighed. Disease incidence (percentage of fruit with anthracnose), mean fruit disease intensity ([ $\Sigma$ (category midpoint*number of fruit in category) $] / n$, where $n=$ number of fruits sampled per replication), and marketable yield (t/ha) were determined for each treatment and cultivar in both years. Data were analyzed by analysis of variance (ANOVA) using SAS statistical software, and means were separated using Fisher's protected least significant difference test. Year by fungicide and year by cultivar data were analyzed using log-transformed values for disease intensity and incidence, and nontransformed data for marketable yield. 


\section{ClustalW Formatted Alignments}

CAOHIO1(CAINT2) AN1(CAINT2) AN2(CAINT2) ATCC 58692 (CAINT2) ATCC 58696 (CAINT2)

CAOHIO1(CAINT2) AN1(CAINT2) AN2(CAINT2) ATCC 58692 (CAINT2) ATCC 58696 (CAINT2)

CAOHIO1(CAINT2)
AN1(CAINT2)
AN2(CAINT2)
ATCC 58692 (CAINT2)
ATCC 58696 (CAINT2)

CAOHIO1(CAINT2) AN1(CAINT2) AN2(CAINT2) ATCC 58692 (CAINT2) ATCC 58696 (CAINT2)

CAOHIO1(CAINT2) AN1(CAINT2) AN2(CAINT2) ATCC 58692 (CAINT2) ATCC 58696 (CAINT2)

CAOHIO1(CAINT2) AN1(CAINT2) AN2(CAINT2) ATCC 58692 (CAINT2) ATCC 58696 (CAINT2)

CAOHIO1(CAINT2) AN1(CAINT2) AN2(CAINT2) ATCC 58692 (CAINT2) ATCC 58696 (CAINT2)

CAOHIO1(CAINT2)
AN1(CAINT2)
AN2(CAINT2)
ATCC 58692 (CAINT2)
ATCC 58696 (CAINT2)

CAOHIO1(CAINT2) AN1(CAINT2) AN2 (CAINT2) ATCC 58692 (CAINT2) ATCC 58696 (CAINT2)

CAOHIO1(CAINT2)
AN1(CAINT2)
AN2(CAINT2)
ATCC 58692 (CAINT2)
ATCC 58696 (CAINT2)

30

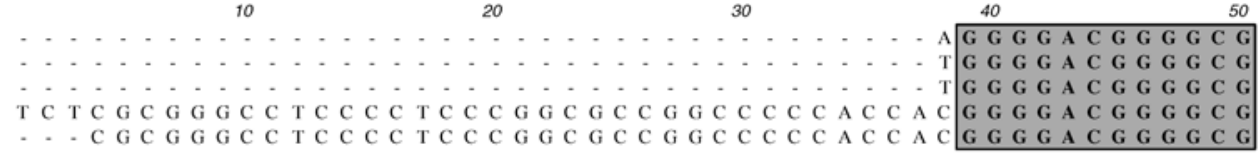

60

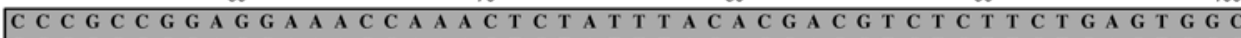
C C C G C C G G A G G A A A C C A A A C T C T A T T T A C A C G A C G T C T C T T C T G A G T G G C C C C G C C G G A G G A A A C C A A A C C C T A T T T A C A C G A C G T C T C T T C T G A G T G G C C C C G C C G G A G G A A A C C A A A C T C T A T T T A C A C G A C G T C T C T T C T G A G T G G C

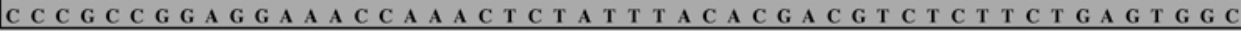

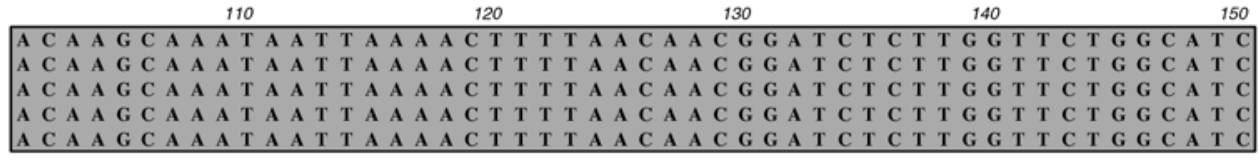

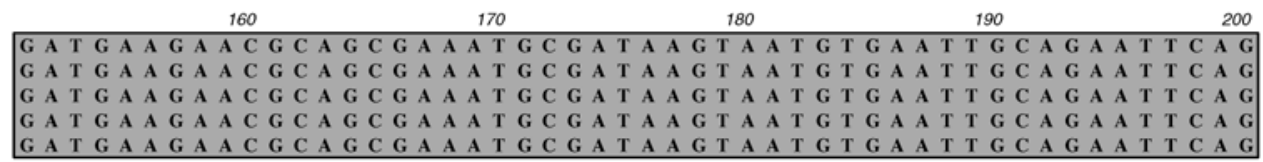

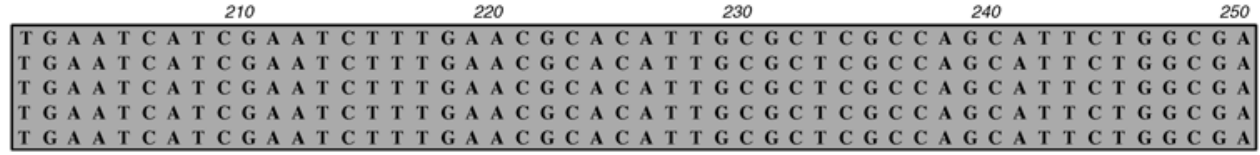

260

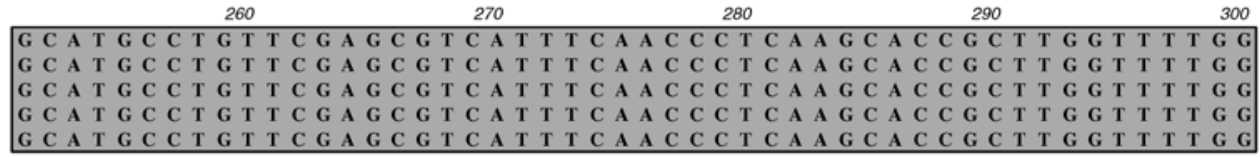

G G C C C C C C A C G G G C A C A C C G T G G G G C C C C T T T A A A G G G T A G

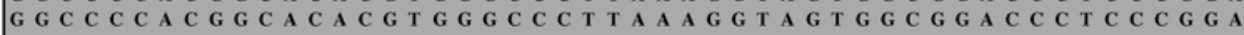

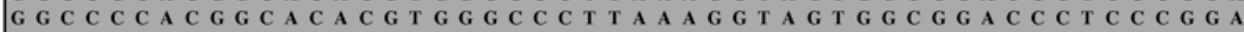

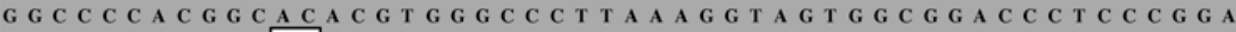
G G C C C C C A C C G G C C C G A C G G T G G G C C C T T T A A A G G T A G T G G C G G G A C C C C T C C C G G A

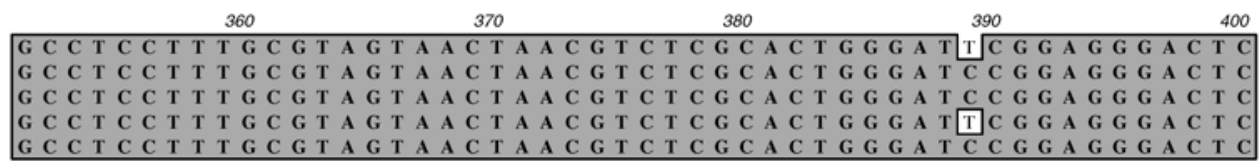

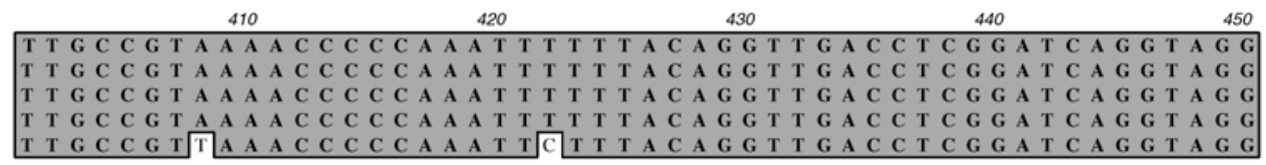

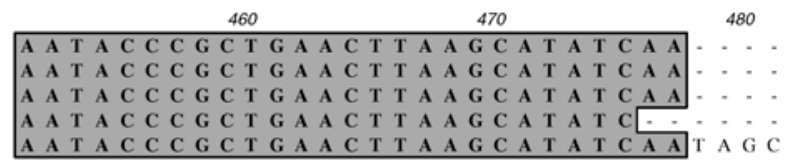

500

Fig. 3. ClustalW sequence alignment of the 490-bp fragment produced during polymerase chain reaction (PCR) with primers CaInt-2/ITS4 of isolates Ca Ohio-1 (Colletotrichum acutatum reference isolate), AN1, AN2, ATCC 58692, and ATCC 58696. Sequence differences are unshaded, deletions are indicated by dashes, and $\mathrm{N}$ indicates an undetermined nucleotide.

\section{RESULTS}

Colony and conidial morphology. Colonies of isolates AN1 and AN2 were effuse, white becoming orange then turning greenish gray as the cultures aged on PDA. Colony reverse was brownish orange to black. Bright orange spore masses were produced outward from the center of the colony. Older cultures developed black acervuli around the center of the colony. No setae were observed. Mycelia were branched, septate, and hyaline. The cultures did not form sectors after 7 days incubation. Conidia were hyaline, unicellu- lar, and cylindrical with obtuse apices and tapering bases (Fig. 2). Average conidial size was $14.7 \times 3.85 \mu \mathrm{m}$.

PCR amplification of genomic DNA with species-specific primers. The $C$. acutatum-specific primer CaInt-2, in conjunction with the ITS4 primer, amplified a 
480-bp fragment from genomic DNA from isolates AN1, AN2, ATCC 58692 and 58696, and the reference $C$. acutatum isolates Ca Ohio-1 and Ca Mil-1 but not from the $C$. gloeosporioides reference isolates GS and GD (Table 4). In contrast, a 450-bp fragment was amplified from genomic DNA of the two C. gloeosporioides reference isolates GS and GD with the $C$. gloeosporioides-specific primer CgInt and the ITS4 primer. CgInt did not amplify a product from the DNA of isolates AN1, AN2, ATCC 58692 and 58696, or the $C$. acutatum reference isolates $\mathrm{Ca}$ Ohio- 1 and Ca Mil-1 (Table 4). No PCR products were produced with water controls in any of the reactions.

Sequencing of PCR products generated from species-specific primers. $\mathrm{Nu}$ cleotide sequences of the CaInt-2 PCR products from genomic DNA of AN1, AN2, ATCC 58692, and ATCC 58696 were compared with those of the $C$. acutatum reference isolate Ca Ohio-1 (Fig. 3). The nucleotide sequence of ATCC 58692 was identical to that of the $C$. acutatum reference isolate $\mathrm{Ca}$ Ohio-1, whereas that of ATCC 58696 differed by five bases, and AN1 and AN2 differed by one base, from that of Ca Ohio-1. Comparisons of these sequences with GenBank, EMBL, DDBJ, and PDB databases (7) showed that the 490-bp sequences of AN1 and AN2 were most similar to those of isolates of $\mathrm{C}$. $\mathrm{acu}$ tatum.

Lesion development and pathogenicity tests on tomato and immature pepper. Isolate $\mathrm{AN} 1$ caused lesions greater than $15 \mathrm{~mm}$ in diameter on wounded and nonwounded mature and immature tomato fruit after 7 days. On wounded pepper fruit, AN1 caused lesions greater than 15 $\mathrm{mm}$ in diameter with an expansion rate of $4.0( \pm 0.037) \mathrm{mm} /$ day. It did not cause lesions on nonwounded pepper fruit. No lesions developed on fruit challenged with water (wounded or nonwounded). Koch's postulates were fulfilled by reisolation of
AN1 from inoculated pepper fruit. Spore shape, size, and colony morphology were identical for the original and recovered isolates.

Pathogenicity tests on strawberry fruit. Isolates Ca Mil-1, AN1, and AN2 caused lesions on 58,58 , and $33 \%$, respectively, of the strawberry fruit inoculated. Fruit challenged with deionized water did not develop lesions.

Cultivar and fungicide field evaluations. In 2001, symptoms appeared 10 days after inoculation, and in 2002, symptoms began to appear 7 days after the second inoculation. Once initial infection began, the disease moved rapidly through the fields. As a result, only one harvest was conducted for each trial. For the fungicide trials, there was no year by fungicide interaction for marketable yield $(P=0.2480)$, percent disease incidence $(P=0.1375)$, or percent disease intensity $(P=0.2106)$. In both years, Cabrio alternated with Manex, Bravo Ultrex, Manex plus Kocide 2000, and Pristine alternated with Manex resulted in significantly lower anthracnose incidence and intensity compared with the untreated control (Table 5). Although Quadris alternated with Manex and Manex alone significantly reduced anthracnose incidence and intensity in 2002, only intensity was significantly reduced in 2001 . Only plants treated with Pristine alternated with Manex produced higher marketable yields than the untreated control in both years. In 2001, Manex plus Kocide 2000 produced significantly smaller fruit than those treated with the other fungicides and the untreated control (data not shown). However, this reduction in fruit size was not observed in 2002.

In the cultivar trials, there was no year by cultivar interaction for percent disease incidence $(P=0.3441)$ or percent disease intensity $(P=0.1235)$; however, a year by cultivar interaction was observed for marketable yield $(P=0.0401)$. Immature fruit of all the cultivars evaluated were suscep- tible to C. acutatum. However, anthracnose intensity and incidence differed significantly among cultivars (Table 6). In both 2001 and 2002, 'Colossal', Brigadier', 'PS304496', and 'Paladin' were among the least susceptible cultivars, and 'Stiletto', 'Crusader', 'Valiant', 'ACX229', 'Red Knight XR3', and 'PR99RY-3' were among the most susceptible. In both years, 'Lafayette', 'Colossal', 'Brigadier', 'PS304496', and 'Paladin' were among the highest yielding cultivars.

\section{DISCUSSION}

Anthracnose has been reported on both immature and mature pepper fruit throughout Asia, but until recently the disease was found primarily on ripe or ripening fruit in the United States $(11,24-$ 28,41). Species of Colletotrichum that have been reported to cause anthracnose on pepper include $C$. capsici $(1,27,39$, 41,43), C. gloeosporioides $(3,11,25,26,40)$, C. piperatum $(28,43,44)$, and $C$. dematium (11). Since the late 1990 s, a severe form of anthracnose that causes lesions on both immature and mature pepper fruit has caused serious yield losses in Ohio and other states (4-6,30,33; S. Miller, unpublished). Our first objective was to identify the species of Colletotrichum causing the disease. Morphological characteristics indicated that the causal agent could be $C$. gloeosporioides or C. acutatum, but culture morphology and conidial characteristics were insufficient to separate the two species. However, PCR with primers specific for both species, followed by nucleotide sequencing of the amplicons, demonstrated that the identity of the causal agent was $C$. acutatum. The nucleotide sequences of DNA amplified from the pepper isolates causing severe symptoms of anthracnose in Ohio were nearly identical (one base pair difference) to those of the reference isolate of $C$. acutatum. This is the first report in the United States of $C$. acutatum causing anthracnose disease on

Table 5. Effect of fungicides on anthracnose incidence and intensity and marketable yield in immature bell pepper fruit during 2001 and 2002

\begin{tabular}{|c|c|c|c|c|c|c|}
\hline \multirow[b]{2}{*}{ Treatments } & \multicolumn{2}{|c|}{ Disease incidence (\%) } & \multicolumn{2}{|c|}{ Mean fruit disease intensity ${ }^{u}$} & \multicolumn{2}{|c|}{ Marketable yield (tons/ha) } \\
\hline & $2001^{v}$ & $2002^{w}$ & 2001 & 2002 & 2001 & 2002 \\
\hline $\begin{array}{l}\text { Quadris 2.08SC } \text { alt. }^{\mathrm{x}} \\
\text { Manex } 37 \mathrm{~F}\end{array}$ & $24.8 \mathrm{a}^{\mathrm{y}}$ & $23.7 \mathrm{bc}$ & $0.56 \mathrm{ab}$ & $1.2 \mathrm{bc}$ & $10.9 \mathrm{ab}$ & $6.0 \mathrm{a}-\mathrm{c}$ \\
\hline $\begin{array}{r}\text { Manex } 37 F+z \\
\text { Kocide } 2000\end{array}$ & $4.3 \mathrm{c}$ & $20.2 \mathrm{bc}$ & $0.13 \mathrm{c}$ & $0.7 \mathrm{bc}$ & $11.8 \mathrm{ab}$ & $5.6 \mathrm{a}-\mathrm{c}$ \\
\hline Manex 37F & $20.0 \mathrm{ab}$ & $16.7 \mathrm{~b}-\mathrm{d}$ & $0.49 \mathrm{~b}$ & $0.6 \mathrm{bc}$ & $9.1 \mathrm{bc}$ & $4.4 \mathrm{~b}-\mathrm{d}$ \\
\hline Bravo Ultrex $82.5 \mathrm{WG}$ & $5.3 \mathrm{c}$ & $13.2 \mathrm{~b}-\mathrm{d}$ & $0.09 \mathrm{c}$ & $0.4 \mathrm{bc}$ & $10.5 \mathrm{a}-\mathrm{c}$ & $8.9 \mathrm{a}$ \\
\hline $\begin{array}{l}\text { Pristine alt. } \\
\text { Manex 37F }\end{array}$ & $8.0 \mathrm{bc}$ & $10.2 \mathrm{~cd}$ & $0.12 \mathrm{c}$ & $0.3 \mathrm{c}$ & $13.3 \mathrm{a}$ & $7.1 \mathrm{ab}$ \\
\hline $\begin{array}{l}\text { Cabrio 20EG alt. } \\
\text { Manex 37F }\end{array}$ & $3.5 \mathrm{c}$ & $2.7 \mathrm{~d}$ & $0.06 \mathrm{c}$ & $0.1 \mathrm{c}$ & $13.8 \mathrm{a}$ & $4.7 \mathrm{~b}-\mathrm{d}$ \\
\hline Untreated & $31.0 \mathrm{a}$ & $73.2 \mathrm{a}$ & $0.84 \mathrm{a}$ & $4.2 \mathrm{a}$ & 8.9 bc & $1.6 \mathrm{~d}$ \\
\hline
\end{tabular}


immature pepper fruit. Interestingly, using the $C$. acutatum-specific primer, a sequence was amplified by PCR from both of the ATCC isolates deposited as $C$. gloeosporioides. The nucleotide sequence of the CaInt2/ITS4 fragment from ATCC 58692 was identical to that of the C. $a c u$ tatum reference isolate, and ATCC 58696 differed from the $C$. acutatum reference isolate by five base pairs, indicating that these isolates may have been misidentified or mislabeled. These data further demonstrate that molecular tools such as PCR with species-specific primers and nucleotide sequencing are useful in distinguishing species of Colletotrichum that could not be distinguished using morphological methods.

In order to develop recommendations for management of this disease, we determined the performance of commercial pepper cultivars under high disease pressure and in separate trials assessed the efficacy of several fungicides in reducing disease incidence and intensity. Although none of the commercial cultivars evaluated exhibited a high level of resistance to anthracnose, significant differences in disease incidence and intensity were observed among cultivars. In both 2001 and 2002, 'Stiletto', 'Crusader', and 'Valiant' were among the most susceptible cultivars. In 2001, 'North Star' and 'Paladin' were among the least susceptible; however in 2002, 'North Star' was only moderately resistant. 'Paladin' exhibits a relatively high level of resistance to the root and crown rot phase of Phytophthora blight (Phytophthora capsici) and therefore may be a good cultivar for regions where Phytophthora blight and anthracnose pressures are high. The fungicides Bravo Ultrex, Manex plus Kocide 2000, Cabrio alternated with Manex, and Pristine alternated with Manex were effective against anthracnose. However, in both years, Cabrio alternated with Manex was the only treatment effective at reducing fruit disease incidence to levels below 5\%. Although Bravo Ultrex was effective at controlling anthracnose and is labeled for many vegetable crops, it is not labeled for peppers in the United States. Pristine alternated with Manex resulted in marketable yields significantly higher than in the untreated control both years, but Pristine also is not labeled for use on peppers at this time. Currently the standard fungicide treatment for the control of anthracnose (caused by C. gloeosporioides and/or C. coccodes) on mature pepper fruit is Maneb (42). However, in our study, Manex only reduced disease incidence on immature pepper in 2002 and in both years was not as effective as other fungicide treatments. Growers in Ohio may consider choosing a fungicide treatment that can control anthracnose on both immature and mature pepper fruit since both Colletotrichum species may be present. In both years, marketable yield for all cultivars and plots treated with fungicides was lower than the average tonnage per acre harvested by growers in Ohio. This was probably the result of high disease pressure and lower plant population density in plots compared with commercial fields.

C. acutatum AN1 caused symptoms on both strawberries and wounded and nonwounded green tomato fruit, indicating that both are hosts of this pepper isolate of C. acutatum. This may have implications for crop rotation strategies in Ohio, where multiple fruit and vegetables crops are commonly produced on the same farm.

Anthracnose caused by $C$. acutatum is an emerging disease that may threaten the profitability of pepper crops in areas where it becomes established. Where market constraints and other diseases or insect pests do not limit the choice of cultivar, cultivars demonstrating at least a moderate level of resistance to $C$. acutatum should be chosen. Since no cultivars have as yet been shown to be highly resistant, fungicides should be applied to protect the crop once the pathogen has been introduced. Strobilurin fungicides are effective in managing the disease, but must always be used in conjunction with one or more fungicides with different modes of action to reduce the likelihood of resistance developing in C. acutatum populations. Additional studies on the etiology and epidemiology of anthracnose are needed to further define disease management strategies.

\section{ACKNOWLEDGMENTS}

We thank M. Ellis, L. Wilson, and T. Sutton for providing isolates of Colletotrichum spp., J. Mera for excellent field support, and B. Bishop for assistance with statistical analyses. We also thank L. Black, Asian Vegetable Research and Development Center, for helpful suggestions, and A. Wszelaki and $\mathrm{M}$. Ellis for critical reviews of this manuscript. This work was supported by The Ohio State University - Ohio Agricultural Research and Development Center and the Ohio Vegetable and Small Fruit Research and Development Program.

\section{LITERATURE CITED}

1. Abdel-Rahman, M. 1974. Fungic. Nematicide Tests 30:126.

2. Adaskaveg, J. E., and Hartin, R. J. 1997. Characterization of Colletotrichum acutatum isolates causing anthracnose of almond and peach in California. Phytopathology 87:979-987.

3. Alexander, S. A., and Pernezny, K. 2003.

Table 6. Effect of cultivar on anthracnose incidence and intensity and marketable yield in immature bell pepper fruit during 2001 and 2002

\begin{tabular}{|c|c|c|c|c|c|c|}
\hline \multirow[b]{2}{*}{ Cultivar } & \multicolumn{2}{|c|}{ Disease incidence (\%) } & \multicolumn{2}{|c|}{ Mean fruit disease intensity ${ }^{y}$} & \multicolumn{2}{|c|}{ Marketable yield (tons/ha) } \\
\hline & 2001 & 2002 & 2001 & 2002 & 2001 & 2002 \\
\hline Crusader & $71.3 \mathrm{a}^{\mathrm{z}}$ & $85.5 \mathrm{ab}$ & $3.0 \mathrm{a}-\mathrm{c}$ & $5.6 \mathrm{ab}$ & $1.6 \mathrm{~g}$ & $2.0 \mathrm{~h}$ \\
\hline Valiant & $70.0 \mathrm{a}$ & $78.5 \mathrm{a}-\mathrm{c}$ & $3.5 \mathrm{a}$ & $4.5 \mathrm{a}-\mathrm{d}$ & $3.6 \mathrm{~d}-\mathrm{g}$ & $4.7 \mathrm{f}-\mathrm{h}$ \\
\hline ACX 229 & $70.0 \mathrm{a}$ & $76.0 \mathrm{a}-\mathrm{d}$ & $2.9 \mathrm{a}-\mathrm{c}$ & $4.6 \mathrm{a}-\mathrm{d}$ & $1.8 \mathrm{~g}$ & $2.4 \mathrm{gh}$ \\
\hline Stiletto & $65.8 \mathrm{ab}$ & $87.2 \mathrm{a}$ & $3.0 \mathrm{ab}$ & $5.8 \mathrm{a}$ & $2.4 \mathrm{fg}$ & $2.7 \mathrm{gh}$ \\
\hline Sir Galahad & $63.3 \mathrm{a}-\mathrm{c}$ & $64.0 \mathrm{c}-\mathrm{f}$ & $2.6 \mathrm{a}-\mathrm{d}$ & $4.0 \mathrm{~b}-\mathrm{f}$ & $4.4 \mathrm{c}-\mathrm{g}$ & $4.9 \mathrm{~d}-\mathrm{h}$ \\
\hline Iron Sides X3R & $59.0 \mathrm{a}-\mathrm{c}$ & $58.0 \mathrm{~d}-\mathrm{h}$ & $2.3 \mathrm{a}-\mathrm{e}$ & $2.8 \mathrm{e}-\mathrm{i}$ & $4.7 \mathrm{c}-\mathrm{g}$ & 8.9 a-e \\
\hline PR99RY-3 & $56.8 \mathrm{a}-\mathrm{d}$ & $69.2 \mathrm{a}-\mathrm{e}$ & $2.5 \mathrm{a}-\mathrm{d}$ & 4.3 a-e & $1.9 \mathrm{c}-\mathrm{g}$ & $2.9 \mathrm{a}-\mathrm{h}$ \\
\hline ACX 217 & $55.8 \mathrm{a}-\mathrm{d}$ & $54.5 \mathrm{e}-\mathrm{h}$ & $2.2 \mathrm{a}-\mathrm{e}$ & $2.8 \mathrm{e}-\mathrm{i}$ & $5.8 \mathrm{c}-\mathrm{f}$ & $9.1 \mathrm{a}-\mathrm{d}$ \\
\hline PR99R-4 & $53.3 \mathrm{a}-\mathrm{e}$ & $64.2 \mathrm{c}-\mathrm{f}$ & $1.4 \mathrm{~d}-\mathrm{f}$ & $3.7 \mathrm{c}-\mathrm{g}$ & $3.8 \mathrm{~d}-\mathrm{g}$ & $5.1 \mathrm{~d}-\mathrm{h}$ \\
\hline Legionaire & $51.8 \mathrm{a}-\mathrm{e}$ & $63.0 \mathrm{c}-\mathrm{g}$ & $1.8 \mathrm{~b}-\mathrm{f}$ & $3.3 \mathrm{c}-\mathrm{h}$ & $4.0 \mathrm{~d}-\mathrm{g}$ & $6.7 \mathrm{a}-\mathrm{g}$ \\
\hline Lafayette & $51.5 \mathrm{a}-\mathrm{e}$ & $58.7 \mathrm{~d}-\mathrm{h}$ & $1.8 \mathrm{~b}-\mathrm{f}$ & $3.3 \mathrm{c}-\mathrm{h}$ & $6.9 \mathrm{a}-\mathrm{d}$ & $7.3 \mathrm{a}-\mathrm{f}$ \\
\hline PR2000-516 & $51.3 \mathrm{a}-\mathrm{e}$ & $61.7 \mathrm{c}-\mathrm{g}$ & $1.7 \mathrm{~b}-\mathrm{f}$ & $3.2 \mathrm{c}-\mathrm{h}$ & $4.9 \mathrm{c}-\mathrm{g}$ & $6.4 \mathrm{~b}-\mathrm{h}$ \\
\hline Red Knight X3R & 50.5 a-e & $71.2 \mathrm{a}-\mathrm{e}$ & $1.7 \mathrm{~b}-\mathrm{f}$ & $4.1 \mathrm{~b}-\mathrm{e}$ & $4.9 \mathrm{c}-\mathrm{g}$ & $4.2 \mathrm{f}-\mathrm{h}$ \\
\hline PR99R-2 & $47.0 \mathrm{~b}-\mathrm{e}$ & $75.0 \mathrm{a}-\mathrm{d}$ & $1.5 \mathrm{c}-\mathrm{f}$ & $4.1 \mathrm{~b}-\mathrm{e}$ & $4.7 \mathrm{c}-\mathrm{g}$ & $5.3 \mathrm{c}-\mathrm{h}$ \\
\hline Colossal & $46.3 \mathrm{~b}-\mathrm{f}$ & $57.7 \mathrm{~d}-\mathrm{h}$ & $1.6 \mathrm{~b}-\mathrm{f}$ & $3.2 \mathrm{c}-\mathrm{h}$ & $6.4 \mathrm{a}-\mathrm{d}$ & 8.9 a-e \\
\hline Commandant & $44.7 \mathrm{~b}-\mathrm{f}$ & $61.7 \mathrm{c}-\mathrm{g}$ & 1.0 ef & $3.1 \mathrm{~d}-\mathrm{h}$ & $5.8 \mathrm{~b}-\mathrm{e}$ & $6.4 \mathrm{a}-\mathrm{h}$ \\
\hline Brigadier & $44.3 \mathrm{~b}-\mathrm{f}$ & $57.2 \mathrm{~d}-\mathrm{h}$ & $1.5 \mathrm{~b}-\mathrm{f}$ & $3.2 \mathrm{c}-\mathrm{h}$ & $9.4 \mathrm{a}$ & $7.6 \mathrm{a}-\mathrm{f}$ \\
\hline $\mathrm{ACX} 220$ & $42.0 \mathrm{c}-\mathrm{f}$ & $78.2 \mathrm{a}-\mathrm{c}$ & $1.2 \mathrm{~d}-\mathrm{f}$ & $4.8 \mathrm{a}-\mathrm{c}$ & $2.7 \mathrm{e}-\mathrm{g}$ & $3.3 \mathrm{f}-\mathrm{h}$ \\
\hline Summer Sweet \#830 & $41.5 \mathrm{c}-\mathrm{f}$ & $76.0 \mathrm{a}-\mathrm{d}$ & $1.3 \mathrm{~d}-\mathrm{f}$ & $4.4 \mathrm{a}-\mathrm{e}$ & $4.2 \mathrm{c}-\mathrm{g}$ & $4.9 \mathrm{~d}-\mathrm{h}$ \\
\hline PS304496 & $35.8 \mathrm{~d}-\mathrm{f}$ & $43.7 \mathrm{~g}-\mathrm{i}$ & 1.0 ef & $1.9 \mathrm{hi}$ & $7.6 \mathrm{a}-\mathrm{c}$ & $8.0 \mathrm{a}-\mathrm{f}$ \\
\hline North Star & 33.0 ef & $67.5 \mathrm{~b}-\mathrm{e}$ & 0.9 ef & $4.4 \mathrm{a}-\mathrm{e}$ & $8.9 \mathrm{ab}$ & $5.6 \mathrm{c}-\mathrm{h}$ \\
\hline Paladin & $24.3 \mathrm{f}$ & $42.0 \mathrm{hi}$ & $0.5 \mathrm{f}$ & $2.3 \mathrm{f}-\mathrm{i}$ & $9.6 \mathrm{a}$ & $10.5 \mathrm{ab}$ \\
\hline
\end{tabular}

${ }^{\mathrm{y}}$ Fruit disease intensity calculated using the weight of fruit in each of four categories and the midpoint value from the categories: 0 lesions, 1 lesion, 2 to 3 lesions, and 4 to 10 lesions ( $\Sigma$ (category midpoint*number of fruit in category)) $/ n$, where $n=$ number of fruits sampled per replication.

$\mathrm{z}$ Values in a column followed by the same letter are not significantly different at $P \leq 0.05$. 
Anthracnose. Pages 9-10 in: Compendium of Pepper Diseases. K. Pernezny, P. D. Roberts, J. F. Murphy, and N. P. Goldberg, eds. American Phytopathological Society, St. Paul, MN.

4. Alexander, S. A., and Waldenmaier, C. M. 2001. Evaluation of fungicides for control of anthracnose in bell pepper, 2000. Fungic. Nematicide Tests (online). Report 56:V30. DOI:10.1094/FN56.

5. Alexander, S. A., and Waldenmaier, C. M. 2002. Management of anthracnose in bell pepper, 2001. Fungic. Nematicide Tests (online). Report 57:V055. DOI:10.1094/FN57.

6. Alexander, S. A., and Waldenmaier, C. M. 2003. Management of anthracnose in bell pepper, 2002. Fungic. Nematicide Tests (online). Report No. 58:V049. DOI:10.1094/FN58.

7. Altschul, S. F., Madden, T. L., Schaffer, A. A., Zhang, J., Zhang, Z., Miller, W., and Lipman, D. J. 1997. Gapped BLAST and PSI-BLAST: A new generation of protein database search programs. Nucleic Acid Res. 25:3389-3402.

8. Braithwaite, K. S., Irwin, J. A. G., and Manners, J. M. 1990. Restriction fragment length polymorphisms in Colletotrichum gloeosporioides infecting Stylosanthes spp. in Australia. Mycol. Res. 94:1129-1137.

9. Braithwaite, K. S., Irwin, J. A. G., and Manners, J. M. 1990. Ribosomal DNA as a molecular taxonomic marker for the group species Colletotrichum gloeosporioides. Aust. Syst. Bot. 3:733-738.

10. Brown, A. E., Sreenivasaprasad, S., and Timmer, L. W. 1996. Molecular characterization of slow-growing orange and key lime anthracnose strains of Colletotrichum from citrus as $C$. acutatum. Phytopathology 86:523-527.

11. Choi, K. S., and Pae, D. H. 1987. Studies on the breeding of resistant varieties of pepper. Res. Rep. RDA (Hort). 29(1):16-23.

12. Cullen, D. W., Lees, A. K., Toth, I. K., and Duncan, J. M. 2002. Detection of Colletotrichum coccodes from soil and potato tubers by conventional and quantitative real-time PCR. Plant Pathol. 51:281-292.

13. Dyko, B. J., and Mordue, J. E. M. 1979. Colletotrichum acutatum. Descriptions of Pathogenic Fungi and Bacteria, No. 630. Commonwealth Mycological Institute, Kew, Surrey, England.

14. Ellett, C. W. 1989. Ohio Plant Disease Index. Ohio State University, Columbus.

15. Ellis, M. A., and Bulger, M. A. 1986. Anthracnose fruit rot (Colletotrichum gloeosporioides) of strawberry in Ohio. Plant Dis. 70:475.

16. Ewing, B., and Green, P. 1998. Base-calling of automated sequencer traces using Phred. II. Error probabilities. Genome Res. 8(3):186194.

17. Ewing, B., Hillier, L., Wendl, M. C., and Green, P. 1998. Base-calling of automated sequencer traces using phred. I. Accuracy assessment. Genome Res. 8(3):175-185.

18. Freeman, S., Pham, M., and Rodriquez, R. J. 1993. Molecular genotyping of Colletotrichum species based on arbitrarily primed PCR, A+Trich DNA and nuclear DNA analysis. Exp. Mycol. 17:309-322.

19. Freeman, S., and Rodriquez, R. J. 1993. Molecular genotyping of Colletotrichum species responsible for anthracnose of strawberry by arbitrarily primed PCR. Mycol. Res. 99:501504.

20. Freeman, S., and Katan, T. 1997. Identification of Colletotrichum species responsible for anthracnose and root necrosis of strawberry in Israel. Phytopathology 87:516-521.

21. Freeman, S., Katan, T., and Shabi, E. 1998. Characterization of Colletotrichum species responsible for anthracnose diseases of various fruits. Plant Dis. 82:596-605.

22. Freeman, S., Minz, D., Jurkevitch, E., Maymon, M., and Shabi, E. 2000. Molecular analyses of Colletotrichum species from almond and other fruits. Phytopathology 90:608-614.

23. Gunnell, P. S., and Gubler, W. D. 1992. Taxonomy and morphology of Colletotrichum species pathogenic to strawberry. Mycologia 84:157-165.

24. Hadden, J. F., and Black, L. L. 1988. Anthracnose of pepper caused by Colletotrichum spp. Pages 189-199 in: Tomato and Pepper Production in the Tropics. S. K. Green, ed. AVRDC, Shanhua, Tainan

25. Kim, B. S., Park, H. K., and Lee, W. S. 1990. Resistance to anthracnose (Colletotrichum spp.) in pepper. Pages 184-188 in: Tomato and Pepper Production in the Tropics. S. K. Green, T. D. Griggs, and B. T. McLean, eds. Proc. Int. Sympos. Integr. Manag. Practices. AVRDC, Shanhua, Taiwan.

26. Kim, W. G., Cho, E. K., and Lee, E. J. 1986. Two strains of Colletotrichum gloeosporioides Penz. causing anthracnose on pepper fruits. Korean J. Plant Pathol. 2:107-113.

27. Kousik, C. S., Ritchie, D. F., Romero, A. M., and Pollard, D. W. 1998. Evaluation of biweekly treatments of Actigard $50 \mathrm{WG}$ for potential control of anthracnose and Erwinia soft rot on bell pepper fruits, 1997. Fungic. Nematicide Tests 53:168.

28. Lambe, R. C., Micales, J. A., and Price, P. L. 1984. Control of anthracnose of pepper with Bravo, 1983. Fungic. Nematicide Tests 39:134.

29. Lee, S. B., and Taylor, J. W. 1990. Isolation of DNA from fungal mycelia and single spores. Pages 282-287 in: PCR Protocols: A Guide to Method and Applications. M. A. Innis, D. H. Gelfand, J. T. Sninsky, and T. J. White, ed. Academic Press, San Diego, CA.

30. Lewis Ivey, M. L., Mera, J., and Miller, S. A. 2003. Evaluation of fungicides and a biocontrol agent for the control of anthracnose on green pepper fruit, 2002. Fungic. Nematicide Tests (online). Report No. 58:V062. DOI:10.1094/FN58.

31. Liyanage, H. D., McMillan, R. T., Jr., and Kistler, H. C. 1992. Two genetically distinct populations of Colletotrichum gloeosporioides from citrus. Phytopathology 82:1371-1376.

32. Manandhar, J. B., and Hartman, G. L. 1995. Anthracnose development on pepper fruits inoculated with Colletotrichum gloeosporioides. Plant Dis. 79:380-383.

33. Miller, S. A., Lewis Ivey, M. L., and Mera, J. 2002. Evaluation of fungicides for the control of anthracnose on green pepper fruit, 2001. Fungic. Nematicide Tests (online). Report No. 57:V054. DOI:10.1094/FN57.

34. Mills, P. R., Hodson, A., and Brown, A. E. 1992. Molecular differentiation of Colletotrichum gloeosporioides isolates infecting tropical fruits. Pages 269-288 in: Colletotrichum: Biology, Pathology and Control. J. A. Bailey and M. J. Jeger, eds. CAB International, Oxford.

35. Mills, P. R., Sreenivasaprasad, S., and Brown, A. E. 1992. Detection of the anthracnose pathogen Colletotrichum. Pages 183-189 in: Modern Assays for Plant Pathogenic Fungi: Identification, Detection and Quantification. A. Schots, F. M. Dewey, and R. Olivers, eds. CAB International, Oxford.

36. Mills, P. R., Sreenivasaprasad, S., and Brown, A. E. 1992. Detection and differentiation of Colletotrichum gloeosporioides isolates using PCR. FEMS Microbiol. Lett. 98:137-144.

37. Mordue, J. E. M. 1967. Colletotrichum coccodes. Descriptions of Pathogenic Fungi and Bacteria, No. 131. Commonwealth Mycological Institute, Kew, Surrey, England.

38. Mordue, J. E. M. 1971. Glomerella cingulata. Descriptions of Pathogenic Fungi and Bacteria, No. 315. Commonwealth Mycological Institute, Kew, Surrey, England.

39. Narain, A., and Panigrahi, C. 1971. Efficacy of some fungicidal compounds to control Colletotrichum capsici in vitro and in vivo. Indian Phytopathol. 24:593-596.

40. Park, W. M., Kim, S. M., and Ko, Y. H. 1989. Susceptibilization of red pepper (Capsicum annuum L.) to Colletotrichum gloeosporioide Pez. in relation to the ripening of fruits. J Plant Pathol. 5:262-270.

41. Roy, K. W., Killebrew, J. F., and Ratnayake, S. 1997. First report of Colletotrichum capsici on bell pepper in Mississippi. Plant Dis. 81:693.

42. Smith, K. L. 2000. Peppers. Pages 166-173 in Ohio Vegetable Production Guide. R. J. Precheur, ed. Ohio State University Extension, Columbus.

43. Smith, R. W., and Crossan, D. F. 1958. The taxonomy, etiology, and control of Colletotrichum piperatum (E. \& E.) E. \& H. and Colletotrichum capsici (Syd.) B. \& B. Plant Dis. Rep. 42:1099-1103.

44. Springer, J. K., and Brown, A. R. 1974. Fungic. Nematicide Tests 30:127.

45. Sreenivasaprasad, S., Brown, A. E., and Mills, P. R. 1992. DNA sequence variation and interrelationships among Colletotrichum species causing strawberry anthracnose. Physiol. Mol. Plant Pathol. 41:265-281.

46. Sreenivasaprasad, S., Mills, P. R., and Brown, A. E. 1994. Nucleotide sequence of the rDNA spacer 1 enables identification of isolates of Colletotrichum as Colletotrichum acutatum. Mycol. Res. 98:186-188.

47. Sreenivasaprasad, S., Sharada, K., Brown, A. E., and Mills, P. R. 1996. PCR-based detection of Colletotrichum acutatum on strawberry. Plant Pathol. 45:650-655.

48. Sutton, B. C. 1992. The genus Glomerella and its anamorph Colletotrichum. Pages 1-26 in: Colletotrichum-Biology, Pathology, and Control. J. A. Bailey and M. J. Jeger, eds. CAB International, Wallingford, UK.

49. White, T. J., Bruns, T., Lee, S., and Taylor, J. 1990. Amplification and direct sequencing of fungal ribosomal RNA genes for phylogenetics. Pages 315-322 in: PCR Protocols, A Guide to Methods and Applications. M. A. Innis, D. H. Gelfand, J. J. Sninsky, and T. J. White, eds. Academic Press, San Diego, CA.

50. Wilson, L. L., Ellis, M. A., and Madden, L. V. 1987. Effect of wetness duration and temperature on infection of strawberry fruit by Colle totrichum acutatum. Phytopathology 77:1752.

51. Wilson, L. L., Madden, L. V., and Ellis, M. A. 1992. Overwinter survival of Colletotrichum acutatum in infected strawberry fruit in Ohio. Plant Dis. 76:948-950. 